\title{
Jubileusz 70-lecia Polskiego Towarzystwa Farmaceutycznego
}

\author{
Bożena Karolewicz ${ }^{1}$, Hanna Plata ${ }^{2}$ \\ ${ }^{1}$ Katedra i Zakład Technologii Postaci Leku, Uniwersytet Medyczny im. Piastów Śląskich we Wrocławiu \\ ${ }^{2}$ Polskie Towarzystwo Farmaceutyczne, Warszawa
}

Adres do korespondencji: Bożena Karolewicz, Katedra i Zakład Technologii Postaci Leku, Uniwersytet Medyczny im. Piastów Śląskich we Wrocławiu, ul Borowska 211A, 50-556 Wrocław, e-mail: bozena.karolewicz@umed.wroc.pl

$\mathrm{P}$ olskie Towarzystwo Farmaceutyczne 30 listopada 2017 r. obchodziło 70-lecie istnienia. Jubileusz był okazją do zorganizowania uroczystej sesji poświęconej temu wydarzeniu. Przedstawiciele zawodu i nauki spotkali się w Sali Kolumnowej Pałacu Prymasowskiego przy ul. Senatorskiej w Warszawie.

Dźwięki „Gaudemater Polonia” rozpoczęly uroczystą sesję. Przybyłych zaproszonych gości: Zbigniewa Niewójta - Głównego Inspektora Farmaceutycznego, Katarzynę Chmielewską - dyrektora Departamentu Nauki i Szkolnictwa Wyższego Ministerstwa Zdrowia, Edytę Gadomską - naczelnika Wydziału Kształcenia w Regulowanych Zawodach Medycznych Ministerstwa Zdrowia, Elżbietę Piotrowską-Rutkowską - prezesa Naczelnej Rady Aptekarskiej, Andrzeja Sawoniego - prezesa Okręgowej Rady Lekarskiej, przedstawicieli Urzędu Rejestracji Produktów Leczniczych, Wyrobów Medycznych i Produktów Biobójczych - dr. Grzegorza Cessaka - prezesa i dr Ewę Leciejewicz-Ziemecką z Departamentu Farmakopei, prof. dr Jadwigę Turło - prorektora Warszawskiego Uniwersytetu Medycznego, dr. Zbigniewa Węgrzyna - przedstawiciela Centrum Medycznego Kształcenia Podyplomowego, prof. dr. Witolda Rużyłlę - dziekana V Wydziału Nauk Medycznych PAN, dr. Wojciecha Kuźmierkiewicza - prezesa Zarządu Naukowej Fundacji Polpharmy, przedstawicieli firmy Servier Polska: Joannę Drewlę, Magdalenę Borkowską i Jacka Szczepańskiego, dziekanów wydziałów farmaceutycznych, przedstawicieli okręgowych izb aptekarskich, redaktorów czasopism farmaceutycznych, przedstawicieli oddziatów terenowych i sekcji naukowych PTFarm, powital prof. dr hab. Janusz Pluta - prezes Polskiego Towarzystwa Farmaceutycznego.
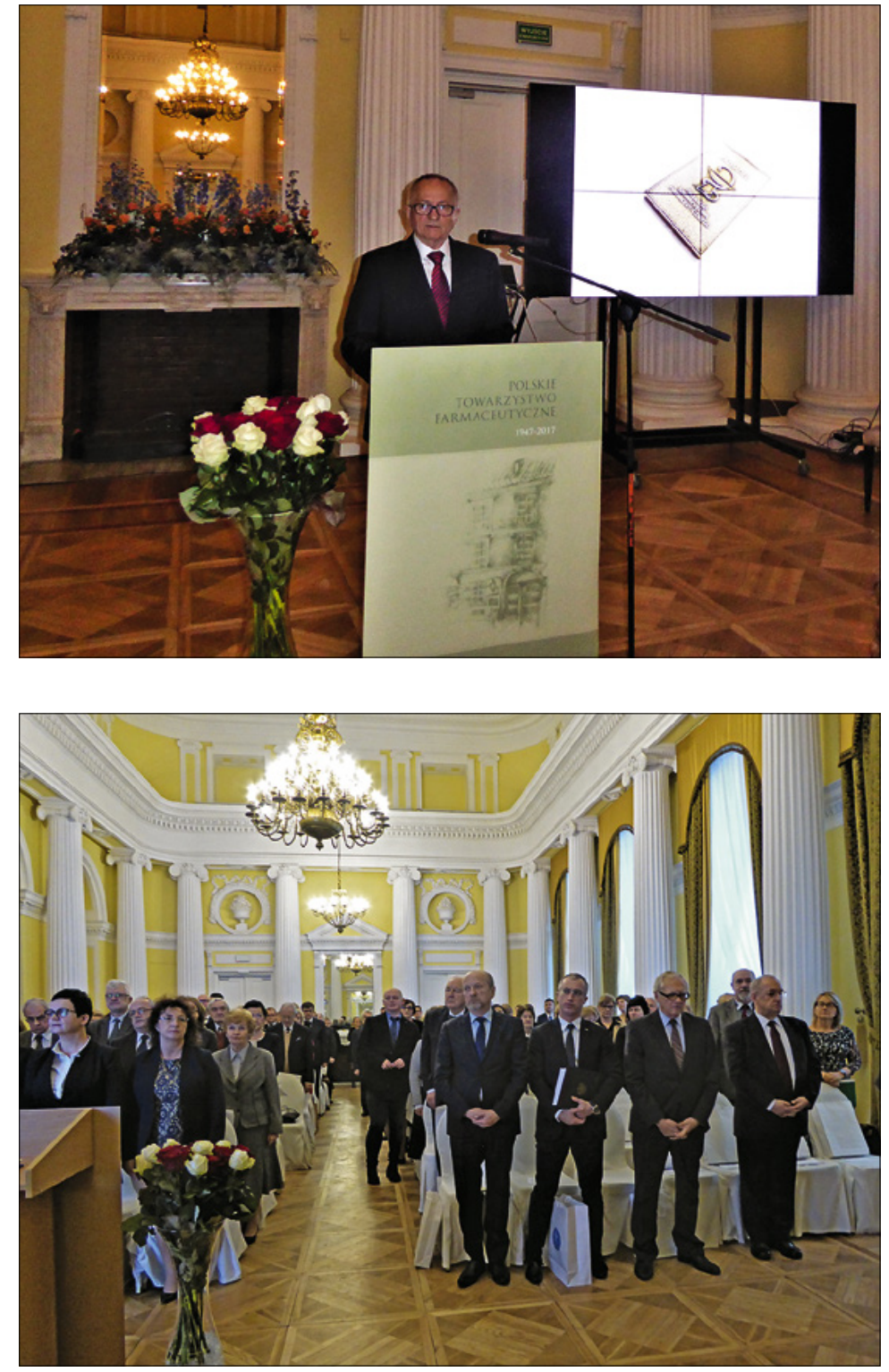

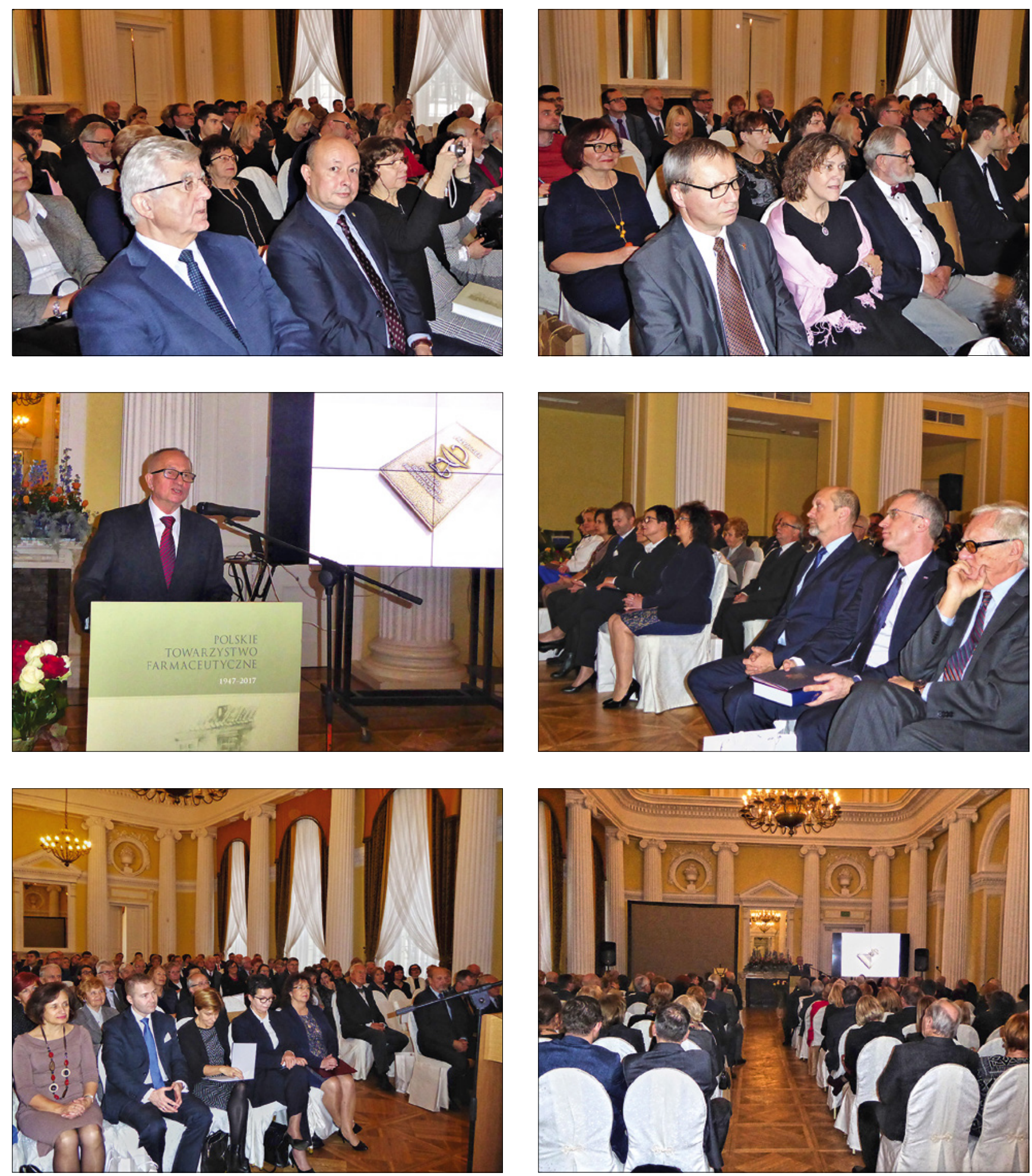

W swoim wystąpieniu okolicznościowym prof. Pluta mówił o znaczeniu, sukcesach i problemach Towarzystwa w jego 70-letniej historii, wspominając wielu zasłużonych członków. Zaprezentował historię, dorobek Towarzystwa oraz nakreślit jego rolę w polskiej farmacji. Powiedziat:

- Rocznica, która stata się okazją do naszego spotkania, jest zaiste niezwykta - 30 listopada mija siedemdziesiąta rocznica powotania do życia Polskiego Towarzystwa Farmaceutycznego. Organizacji, której celem nadrzędnym jest nie tylko podnoszenie naukowego $i$ fachowego poziomu farmaceutów czy propagowanie postępów nauki $w$ tej dziedzinie, ale także czuwanie nad catoksztattem rozwoju i stanowiska farmacji $w$ Rzeczypospolitej Polskiej.[...] 

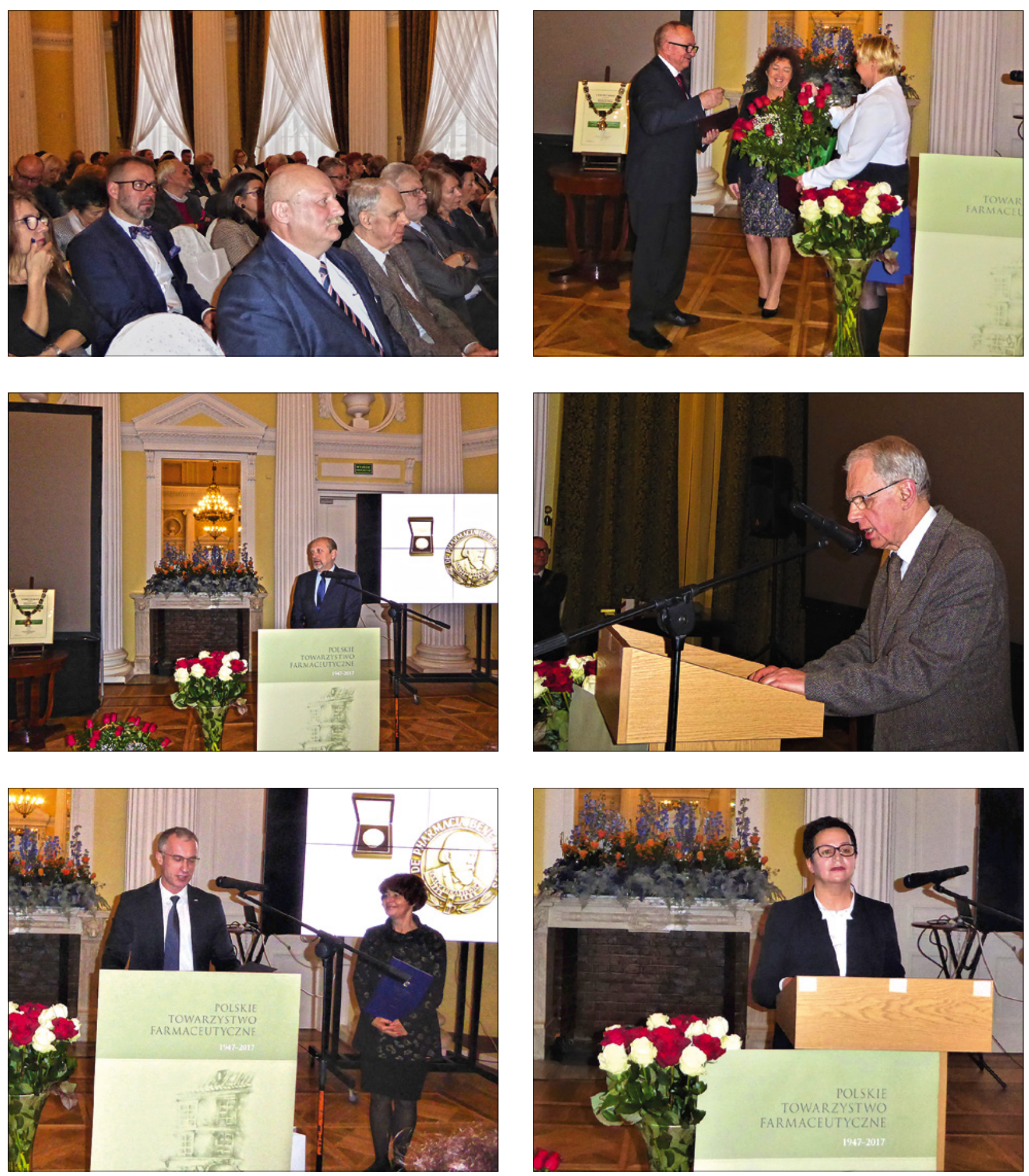

patrząc na aktywność $i$ dokonania Polskiego Towarzystwa Farmaceutycznego na przestrzeni tych siedemdziesięciu lat, śmiem twierdzić, że idea o niezbędności ścistego zwiazku nauki $z$ praktyka farmaceutyczna jest ze wszech miar stuszną.

Odniósł się również do roli farmaceutów w życiu Polaków:
- Dziś Polskie Towarzystwo Farmaceutyczne zrzesza tysiąc ośmiuset członków, którzy swoja dziatalnością $i$ codzienna praca udowadniaja, że farmaceuta to nie tylko dyspozytariusz środków leczniczych, ale przede wszystkim pierwszy partner $w$ rozwiązywaniu problemów zdrowotnych Polaków, których codziennie dwa miliony otwiera drzwi aptek. 

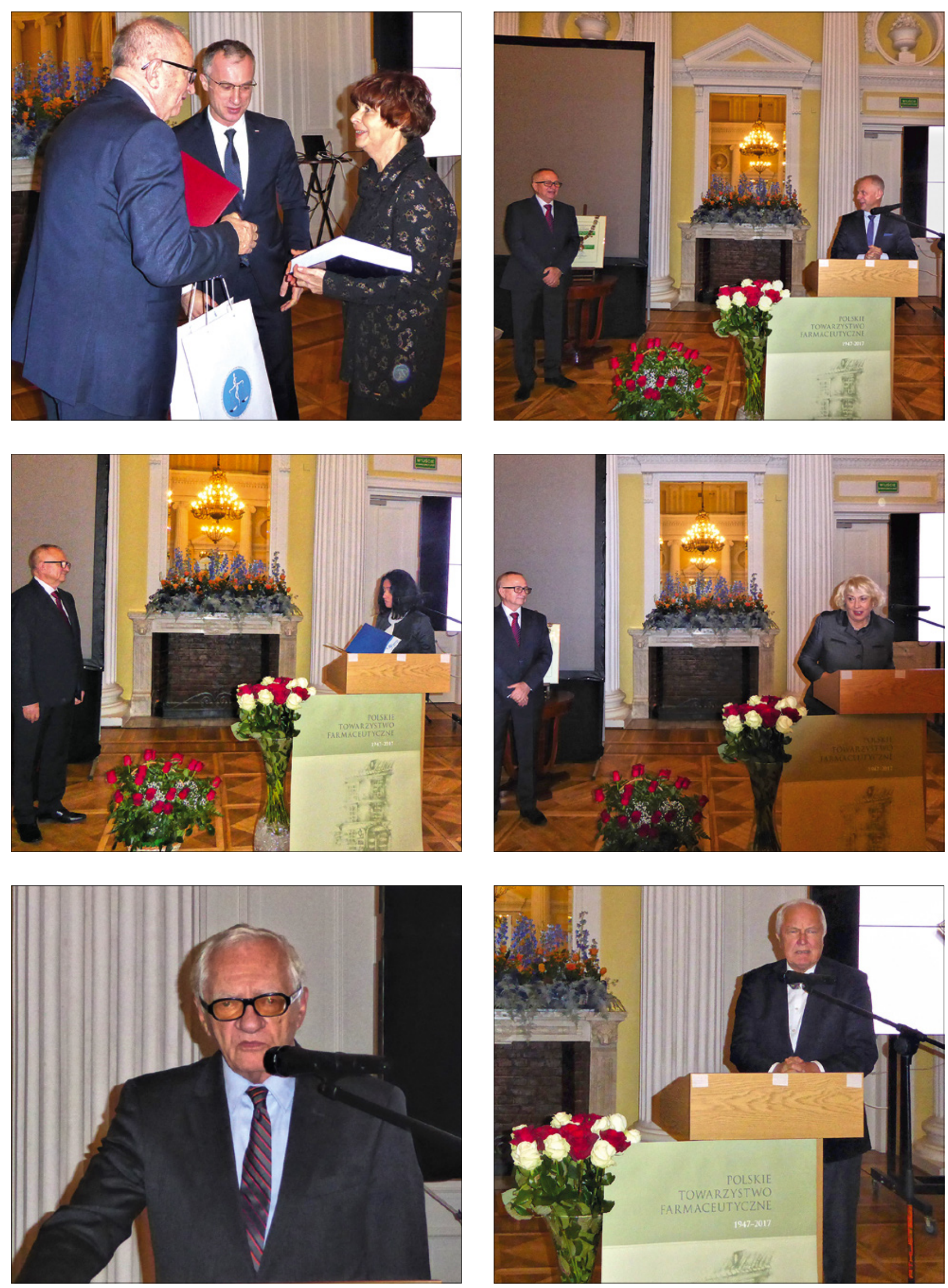


\section{fig WYDARZENIA}
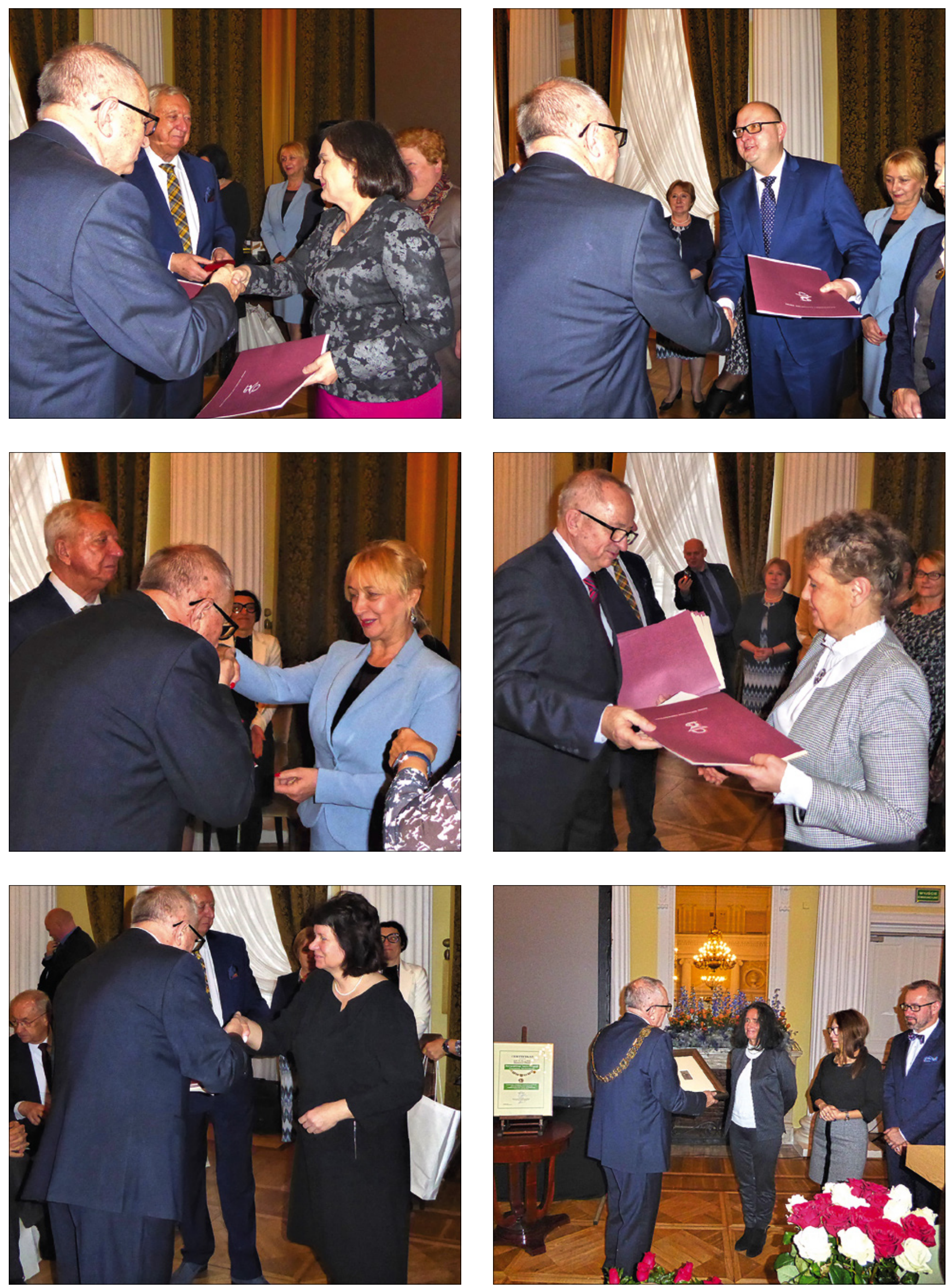

fip- Tom 74 $\cdot$ nr 2.2018 

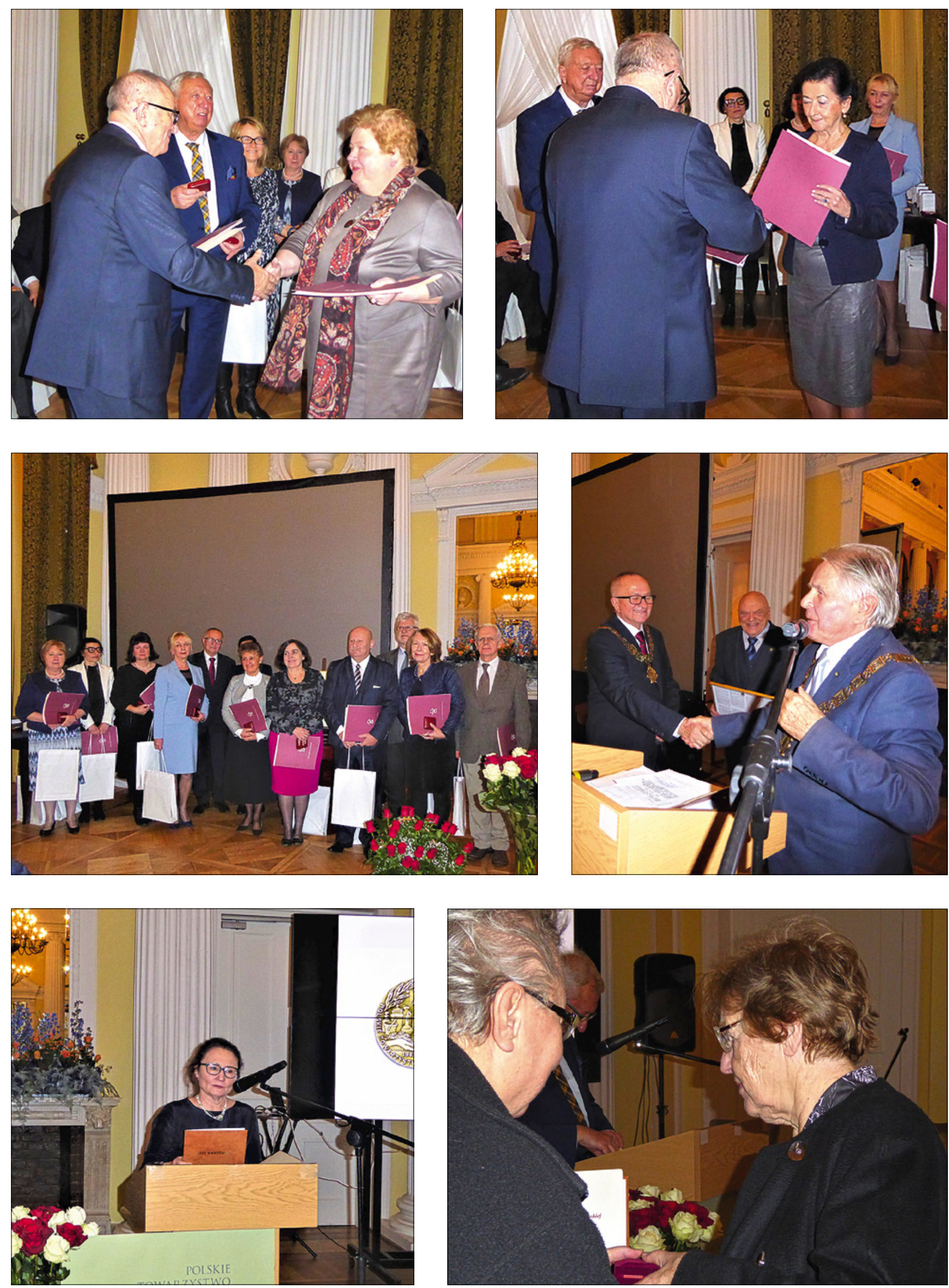

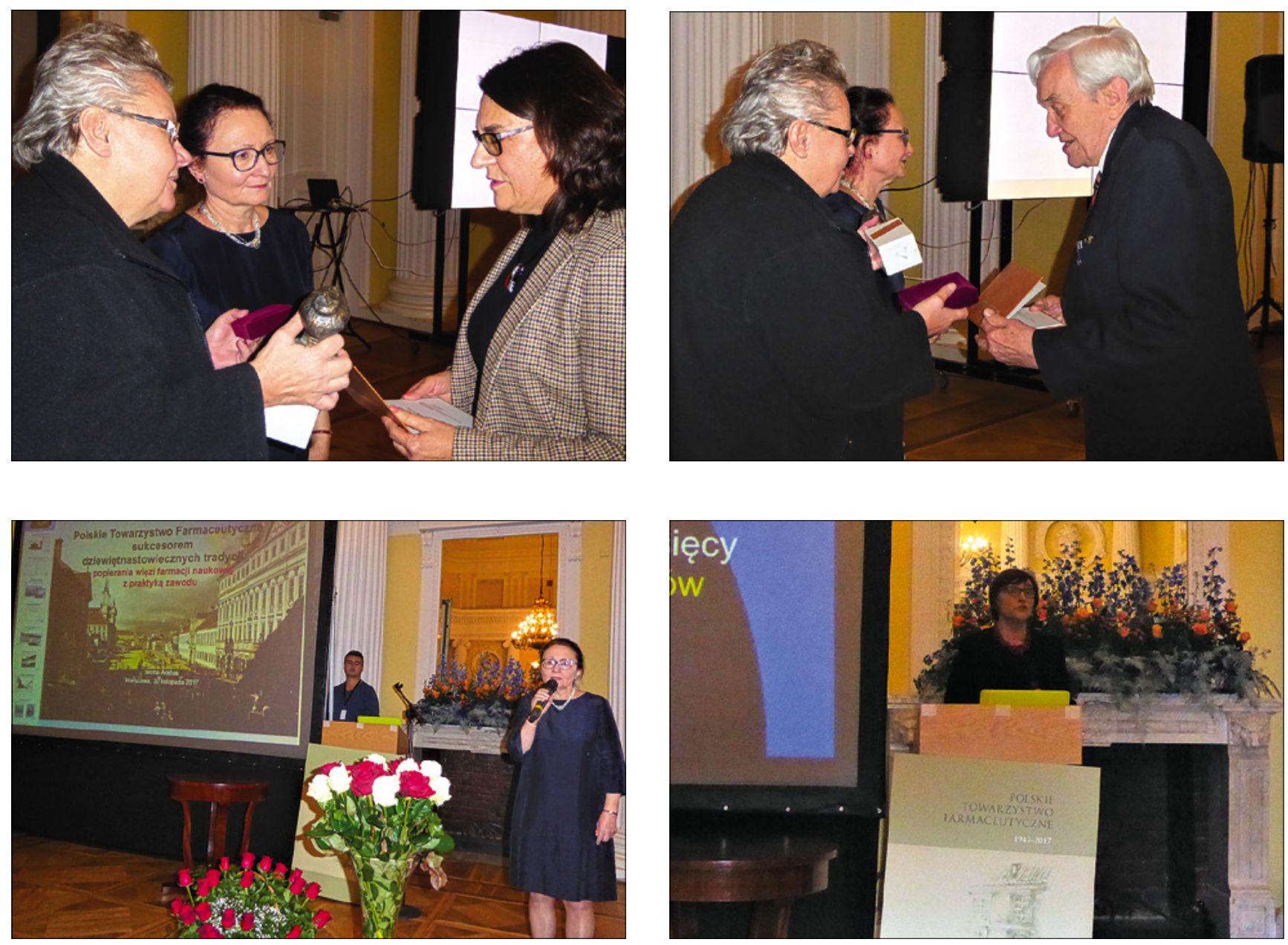

Z dużym uznaniem mówił o wszystkich, którzy tworzyli i mieli wpływ na kształt Towarzystwa:

- Moje wystapienie bytoby niepetne, gdybym nie wspomniat tu o ludziach, którzy przez ostatnie siedemdziesiąt lat tworzyli $i$ ksztattowali te organizację, dziatając spotecznie na rzecz farmacji naukowej na terenie catej Polski. Wszak żadna idea, żadne przedsięwzięcie nie jest możliwe bez pracy i wysitku cztowieka.

Prof. Pluta zaproponowat uczczenie minutą ciszy zmarłych członków i działaczy Towarzystwa.

Przemówienia okolicznościowe wygłosili również zaproszeni goście, składając na ręce prezesa podziękowania i gratulacje.

Zasłużonym członkom Towarzystwa wręczono także odznaczenia i nagrody. Medale im. Ignacego Łukasiewicza otrzymali: dr hab. Michał Tomczyk (Białystok), prof. dr hab. Małgorzata Sznitowska (Gdańsk), dr n. farm. Lucyna Bułaś (Katowice), prof. dr hab. Renata Jachowicz (Kraków), prof. dr hab. Gabriel Piotr Nowak (Kraków), dr n. farm. Mariola Drozd (Lublin), prof. $\mathrm{dr}$ hab. Monika Waksmundzka-Hajnos (Lublin), dr Wojciech Giermaziak (Łódź), mgr farm. Aleksandra Maria Burek (Opole), mgr farm. Anna

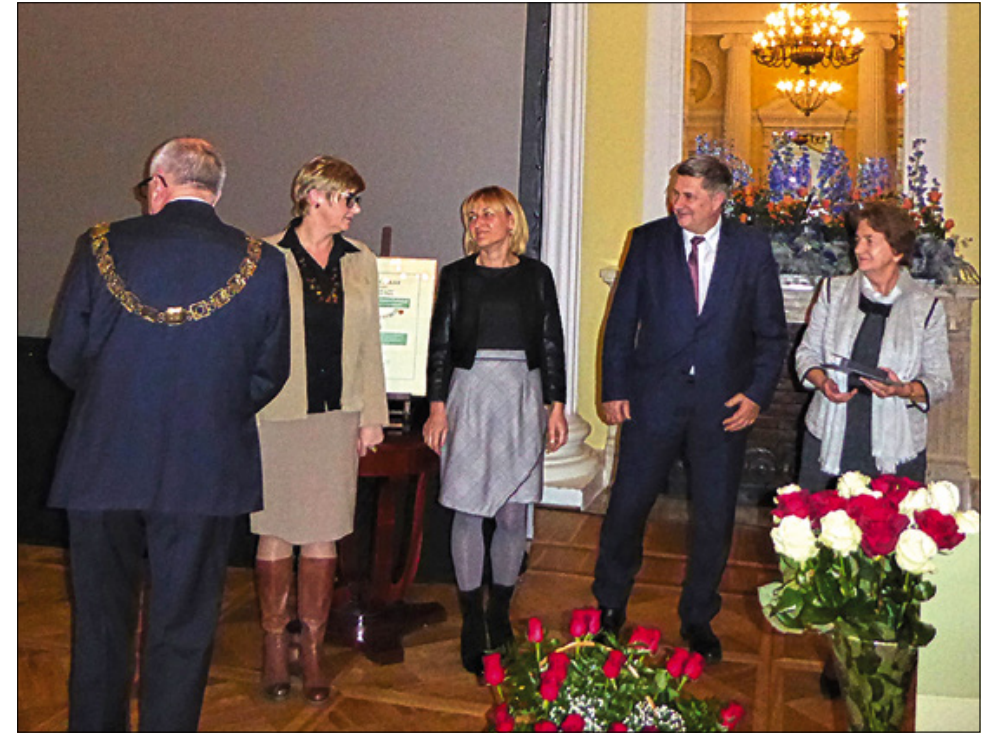

Jadwiga Łohynowicz - O. Poznań, dr n farm. Elżbieta Maria Ziółkowska (Poznań), prof. dr hab. Helena Elżbieta Makulska-Nowak (Warszawa), prof. dr hab. Agnieszka Irena Pietrosiuk (Warszawa), dr hab. Bożena Lucyna Karolewicz (Wrocław), prof. dr hab. Piotr Szefer (Gdańsk). W imieniu 


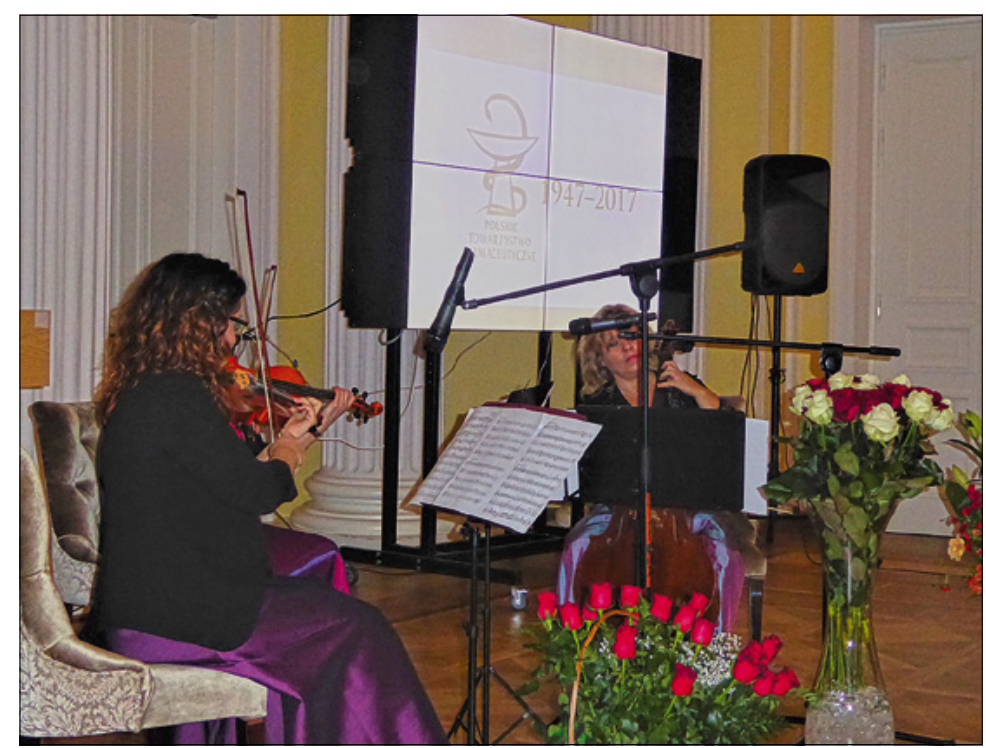

nagrodzonych za wyróżnienia podziękowal prof. Piotr Szefer.

Miłym akcentem spotkania było wręczenie czterem osobom, szczególnie zasłużonym dla środowiska historyków farmacji, statuetek im. Antoniny Leśniewskiej. Statuetka została ustanowiona z okazji ważnych dla polskiego środowiska farmaceutycznego jubileuszy przypadających w 2017 r. - 200-lecia „Farmakopei Polskiej” oraz 70-lecia Polskiego Towarzystwa Farmaceutycznego i będzie przyznawana przez Zarząd Ogólnopolskiej Sekcji Historii Farmacji Polskiego Towarzystwa Farmaceutycznego tym wszystkim, którzy wnieśli duży wkład w rozwój historii farmacji w Polsce. Otrzymali je: prof. Bożenna Gutkowska, prof. Janusz Pluta, prof. Aleksander Drygas i prof. Janusz Durko. W imieniu prof. Durki, który zmarł w wieku 104 lat przed wręczeniem nagrody, statuetkę odebrała córka Profesora Magdalena Durko-Stępień.

Ceremonię uświetnił występ trio smyczkowego Salonów Warszawy. Półgodzinny koncert muzyki klasycznej i standardów muzyki światowej był znakomitą oprawą jubileuszu.

Uczestnicy wysłuchali również dwóch wykładów plenarnych. Wykład nawiązujący do historii Polskiego Towarzystwa Farmaceutycznego wygłosiła prof. dr hab. Iwona Arabas - „Polskie Towarzystwo Farmaceutyczne sukcesorem dziewiętnastowiecznych tradycji”. Kolejny wykład „Nadszedt czas zmian - znaczenie farmacji klinicznej i opieki farmaceutycznej w zwiększeniu skuteczności i bezpieczeństwa farmakoterapii” zaprezentowała prof. dr hab. Anna Wiela-Hojeńska.

Podsumowując jubileusz, prof. Janusz Pluta podziękował przybyłym gościom, władzom i członkom Towarzystwa oraz pracownikom Biura Zarządu Głównego za zaangażowanie w pracę na rzecz Towarzystwa, życząc jednocześnie dalszych sukcesów w życiu zawodowym i deklarując zaangażowanie Towarzystwa w prace na rzecz środowiska farmaceutycznego zarówno naukowego, jak i zawodowego.

Zdjęcia: Hanna Plata

Otrzymano: 2018.01.04 - Zaakceptowano: 2018.01.15 